\title{
Akut miyokard infarktüsü seyrinde periferik kök hücre ve beyaz küre sayımının ekokardiyografik ve klinik parametreler ile korelasyonu
}

\section{Correlation of white blood cell count and periferic stem cell count with echocardiographic and clinical parameters in the setting of acute myocardial infarction}

\author{
Özgür Taşköylü, Taner Değirmenci, Halil Tanrıverdi
}

Gönderilme tarihi:26.10.2021

Kabul tarihi:06.12.2021

\section{Öz}

Amaç: İnflamasyon aterosklerozun ve klinik komplikasyonlarını önemli bir komponentidir. Bu sebeple; akut miyokard infarktüsü seyrinde inflamatuvar belirteçlerin kullanımı giderek önem kazanmaktadır. Lökositler bu inflamatuvar süreçte belirgin rol oynamaktadır. Son dönemde akut miyokard infarktüsü seyrinde kök hücre infüzyonu tedavileri yoğun bir şekilde incelenmiştir. Bu çalışmada farklı olarak; spontan periferik kök hücre mobilizasyonun ve beyaz küre altgrup sayımlarının; akut miyokard infarktüsü sonrası sol ventrikül fonksiyonlarındaki düzelme ile ilişkisinin ekokardiyografik olarak incelenmesi amaçlanmışıır.

Gereç ve yöntem: Çalışmamıza akut miyokard infarktüsü nedeniyle kliniğimize başvuran 28 hasta dahil edilmiştir. Yirmi hastaya primer PKG uygulanmış olup 8 hastaya doku plazminojen aktivatörü (t-PA) infüzyonu yapılmıştır.

Bulgular: Lenfosit değerlerinin AMI seyrinde düşüş gösterdiği ve 30. gün kontrollerinde de düşük olarak saptandığı görülmüştür. Bazal lenfosit sayımları CK-MB ile güçlü ve troponin-I ile orta düzeyde negatif korele olarak saptanmıştır $(r=-0,668, p=0,001$ ve $r=-0,465, p=0,01)$. Lenfosit düzeyleri ile sol ventrikül ejeksiyon fraksiyonu (SVEF) arasında pozitif korelasyon saptanırken Duvar /ıareket skor indeksi (DHSi) ile negatif korelasyon saptanmıştır $(r=0,403, p=0,03$ ve $r=-0,598, p=0,01)$. CD34 (+) kök hücre düzeyleri ile SVEF'deki değişim arasında pozitif korelasyon saptanmıştır $(r=0,585, p=0,005)$ CD34 (+) kök hücre düzeyleri ile DHSi'deki değişim arasında orta düzeyde negatif korelasyon saptanmışıิır $(r=-0,562, p=0,008)$. AMI seyri sırasında; periferik lenfosit düzeylerinin SVEF, DHSi değerlerindeki değişimler ve kardiyak enzim ile korele olduğu saptanmıştır. Periferik CD34 (+) kök hücre düzeyleri ise SVEF, DHSi gibi ekokardiyografik parametreler ile korele olarak saptanmıştır.

Sonuç: Verilerimiz; lenfositlerin AMI seyrinde aktif rollerinin olduğunu ve lenfopeni düzeylerinin biyomarker olarak kullanılabileceğini düşündürmektedir.

Anahtar kelimeler: Akut miyokard infarktüsü, lenfosit, kök hücre.

Taşköylü Ö, Değirmenci T, Tanrıverdi H. Akut miyokard infarktüsü seyrinde periferik kök hücre ve beyaz küre sayımının ekokardiyografik ve klinik parametreler ile korelasyonu. Pam Tıp Derg 2022;15:149-157.

\begin{abstract}
Purpose: Inflammation is the core component of aterosclerosis and its complications. For this reason, use of inflammatory biomarkers in the setting of acute miyocardial infarction has been gaining more impotance day by day. Leucocytes has the major role in this inflammatory process. Stem cell infusion therapies were investigated deeply in the setting of acute myocardial infarction. In this study; unlike those we aimed to investigate the relationship between spontaneous stem cell mobilization, differential white blood cell count and left ventricular functional recovery after acute myocardial infarction.

Materials and methods: We evaluated 28 patients with acute myocardial infarction. Twenty of the patients undergone percutaneus coronary intervention and eight of them recieved tissue-plasminogen activator (t-PA) infussion.

Results: Lymphocyte counts were depressed in acute myocardial infarction and remain depressed at the one month follow-up. Lymphocyte counts were strongly negative correlated with CK-MB and modaretely negative corralated with troponin-I $(\mathrm{r}=-0.668, p=0.001$ ve $\mathrm{r}=-0.465, p=0.01)$. Lymphocyte counts were positively correlated with left ventricular ejection fraction (LVEF); and negatively corralated with wall motion score indexes (WMSI) $(r=0.403, p=0.03$ ve $r=-0.598, p=0.01)$. CD34 ( + ) stem cell counts were positively correlated with LVEF recovery $(\mathrm{r}=0.585, p=0.005)$. CD34 $(+)$ stem cell counts were negatively corralated with WMSI $(\mathrm{r}=-0.562, p=0.008)$. Peripheral lymphocyte counts seem to be correlated with changes in LVEF, WMSI and cardiac enzymes. Peripheral CD34 (+) stem cell counts seem to be correlated with changes in LVEF, WMSI the setting of acute myocardial infarction.
\end{abstract}

Özgür Taşköylü, Uzm. Dr. Denizli Özel Sağlık Hastanesi, Kardiyoloji Kliniği, Denizli, Türkiye, e-posta: ozgurtaskoylu@gmail.com (https://orcid. org/0000-0000-0002-0050-1820)

Taner Değirmenci, Uzm. Dr. Denizli Özel Sağlık Hastanesi, Psikiyatri Kliniği, Denizli, Türkiye, Tanerd75@gmail.com (https://orcid.org/00000002-6810-9710) (Sorumlu Yazar)

Halil Tanrıverdi, Prof. Dr. Pamukkale Üniversitesi Tıp Fakültesi, Kardiyoloji Anabilim Dalı, Denizli, Türkiye, e-posta: drhaliltanriverdi@yahoo. com.tr (https://orcid.org/0000-0001-9596-0044) 
Conclusion: Our data, declines the active role of lymphocytes in the course of AMI and the probability of the usage of lymhopenia levels as a biomarker.

Key words: Acute myocardial infarction, lenfosit, stem cell.

Taskoylu O, Degirmenci T, Tanriverdi H. Correlation of white blood cell count and periferic stem cell count with echocardiographic and clinical parameters in the setting of acute myocardial infarction. Pam Med $J$ 2022;15:149-157.

\section{Giriş}

Aterosklerozun inflamatuar bir hastalık olduğu uzun zamandan beri bilinmektedir [1]. Akut koroner sendromlar; plak fissür, rüptür ya da erozyonu gelişen alanlardaki koroner tromboz sonucu [2]. Fibröz kapsül hasarı da inflamatuar hücrelerin biriktiği alanlarda izlenmektedir [3]. Ayrıca inflamasyonun akut koroner sendrom seyri sırasında aterotromboz ve reperfüzyon hasarı gibi temel faktörler üzerinde önemli etkisi bulunmaktadır [4].

Lökosit sayımı klinik uygulamada yaygın olarak kullanılan bir inflamasyon belirtecidir. Lökositozun koroner arter hastalığı üzerindeki etkisi inflamasyonu düzenleyen birçok fizyopatolojik mekanizma üzerinden gerçekleşmektedir. Bunlar arasında endotelyal hücrelere oksidatif ve proteolitik hasar, mikrovasküler tıkanma; hiperkoagülabilitenin tetiklenmesi ve infarkt ekspansiyonu sayılabilir [5-8]. Nötrofil, monosit eozinofil ve trombositlerin kardiyovasküler hastalık üzerindeki etkileri değişik çalışmalar ile gösterilmiştir $[9,10]$. Lökositoz kardiyovasküler hastalık seyrinden ayrı olarak, bağımsız bir risk faktörü ve prognostik belirteçtir. Ancak çok ucuz, kolay, tekrarlanabilen rutin bir tetkik olmasına rağmen diagnostik ve prognostik olarak yaygın kullanıma girmemiştir.

Bununla beraber akut kardiyovasküler olay seyri sırasında periferik kana salınımı artan bir başka hücre topluluğu olan kemik iliği kaynaklı kök hücreler de hem prognostik hem teröpatik önemi nedeniyle araştırıcılarının dikkatlerini üzerine çekmektedir. Akut koroner sendrom seyri sırasında çeşitli kemotaktik ve inflamatuar faktörlerin etkisiyle kemik iliği kaynaklı endoteliyal progenitör hücrelerin mobilizasyonu artmaktadır. $\mathrm{Bu}$ hücreler neovaskülarizasyon bölgesine giderek endotel hücrelerine dönüşebilmektedirler. Kemik iliği kaynaklı kök hücrelerin periferik kandaki miktarı artırılarak veya intrakoroner kök hücre injeksiyonu ile miyokardiyal rejenerasyon ve neovaskülarizasyon üzerinde olumlu etkiler sağlanabilmektedir [11, 12]. Bu çalışmanın temel amacı; akut miyokard infarktüsü seyrinde; total ve diferansiyal lökosit sayımı ile periferik kök hücre sayımının klinik ve ekokardiyografik parametreler ile ilişkisini değerlendirmektir.

\section{Gereç ve yöntem}

\section{Hasta popülasyonu}

$\mathrm{Bu}$ çalışmaya ilk kez ST segment elevasyonlu AMI nedeniyle başvuran; 18 yaş ve üzeri 30 ardışık hasta çalışmaya dahil edilmiştir. Çalışmaya katılan hastaların 22 si erkek olup tüm hastaların yaş ortalaması 56,3 \pm 11 yıl olarak saptanmıştır. Çalışma, Pamukkale Üniversitesi Girişimsel Olmayan Etik Kurulu tarafından onaylanmıştır. Çalışmaya katılan tüm hastalar gönüllülük esasına göre belirlenmiş olup; katılan her hastadan bilgilendirilmiş onam formu alınmıştır. Yirmi dakikadan uzun süreli iskemik kökenli göğüs ağrısı olan hastalarda ST segment elevasyonlu MI tanısı troponin I düzeylerinin $0,1 \mathrm{ng} / \mathrm{ml}$ üzerine çıkması ile birlikte $\mathrm{J}$ noktasından $80 \mathrm{~ms}$ sonra ölçülen ST segmentinde; 2 ardışık derivasyonda; V1-3 arası en az 0,2 $\mathrm{mm}$ diğer derivasyonlarda en az $0,1 \mathrm{~mm}$ elevasyon esas alınarak Amerika ve Avrupa Kardiyoloji Derneklerinin kriterleri kullanılarak konulmuştur [13].

Çalışmaya göğüs ağrısı başlangıcından itibaren ilk 12 saat içerisinde başvuran başarıı $\mathrm{PCl}$ ya da trombolitik tedavi uygulanan hastalar alınmıştır. 20 hastaya primer PTCA 8 hastaya alteplaz uygulanmıştır. Hastaların tedavileri Avrupa Kardiyoloji Derneği önerilerine göre düzenlenmiştir [14].

Kronik renal yetmezliği, ileri karaciğer hastalığı, malignitesi, kronik inflamatuar hastalığı ya da aktif enfeksiyöz durumu olanlar ile steroid kullananlar çalışma dışında bırakılmıştır. İki hasta takipleri yapılamadığı için çalışma dışında bırakıımıştır. Başvuru sırasında ciddi kalp yetmezliği (Killip III-IV) ve kardiyojenik şok tablosunda olan hastalar çalışmaya 
dahil edilmemiştir. Kalan 28 hasta çalışma kapsamında takip eden 10 ve 30 . günlerde rutin laboratuar testleri ve ekokardiyografik parametreler açısından izleme alınmıştır.

\section{Klinik veriler}

Hastaların tam medikal öyküleri alınarak; yaş cinsiyet, HT, hiperlipidemi, DM, sigara ve aile öyküsü gibi demografik veriler kaydedilmiştir. Hastaların başvuru sırasında ve takiplerinde sistolik ve diastolik kan basıncı değerleri, kalp hızı, Killip sınıfı gibi fizik muayene verileri kaydedilmiştir.

\section{EKG analizi}

On iki derivasyonlu EKG analizi reperfüzyon terapisi öncesinde, 1 saat sonra ve hastanın yatış süresi boyunca günlük olarak ve 10 ve 30. günlerde uygulanmıştır. ST segment rezolüsyonu revaskülarizasyon sonrası 90 . dakikada bazal değere göre $\% 50$ ve daha fazla azalma olması olarak kabul edilmiştir. Hastaların başlangıçtaki ST elevasyonları olan derivasyonları ile takip eden günlerde patolojik $Q$ dalgası gelişimi kayıt edildi.

\section{Ekokardiyografik analiz}

Çalışmada 2 boyutlu ekokardiyogram verileri General Elektrik Vivid 7 (Horton, Norveç) cihazı aracılığıyla elde edilmiştir. Hastaların hastaneye kabulünde ve sonrasındaki 10. ve 30. günlerde ekokardiyografik incelemeleri yapılarak sol ventrikül fonksiyonları, bölgesel duvar hareket skorları ve sol ventrikül volümleri takip edilmiştir. Sol ventrikül ejeksiyon fraksiyonu Simpson metodu ile hesaplanmıştır. Bölgesel duvar hareket skoru (WMSI) değerlendirmesi American Society of Echocardiography'nin önerilerine göre 16 segment üzerinden yapılmıştır. Bu skorlama sistemine göre sol ventrikül üzerindeki segmentler 1-normokinetik 2-hipokinetik 3-akinetik 4-diskinetik 5anevrizmatik olarak değerlendirilmiştir. Bölgesel duvar hareket skoru segmentlerin skorları toplamının gözlemlenebilen segment sayısına bölünmesi ile elde edilmiştir [15].

\section{Koroner angiografi ve primer koroner angioplasti}

Primer angioplasti için uygun olan grupta başvuru sonrası 90 dakika içerisinde koroner angioplasti yapıldı ve akut hadiseden sorumlu artere revaskülarizasyon uygulandı. Primer koroner angioplasti uygulanan grupta lezyondan sorumlu damar dışındaki arterlerde saptanan klinik olarak anlamlı lezyonlara elektif olarak revaskülarizasyon uygulaması yapılmıştır. Primer perkutan koroner angioplasti yapılan tüm hastalarda $\% 20$ ve altında stenoz düzeyi ve TIMI 3 akım düzeyi elde edilmiştir. Trombolitik tedavi (alteplaz) uygulanan grupta taburculuk öncesi 2-5. günler arasında konvansiyonel koroner angiografi ve gerekirse elektif koroner stent uygulaması yapılmıştır. Koroner aterosklerozun ciddiyetinin ciddiyetinin belirlenmesi amacıyla Gensini skorlama sistemi kullanılmıştır. Gensini skorlama sistemine göre \%1-25 darlık 1 puan, \%26-50 darlık 2 puan, \%51-75 darlık 4 puan, \%76-90 darlık 8 puan, \%91-99 darlık 16 puan, total oklüzyon 32 puan olarak değerlendirilmiş olup, skor lezyonun kroroner ağaçtaki yerleşimine göre belirli bir katsayı ile çarpılmıştır. Bu katsayı değeri sol ana koroner için 5, proksimal LAD ve $C x$ için 2,5, mid LAD için 1,5, distal LAD ile mid-distal $\mathrm{Cx}$ için 1 olarak alınmıştır [16].

\section{Beyaz küre sayımı ve laboratuar analizleri}

Total beyaz küre ve lenfosit, nötrofil ve trombositsayımları standartotomatikhematolojik sayım cihazları ile değerlendirilmiştir. Beyaz küre düzeyleri başvuru sırasında, 4, 8, 12, 24, 48. saatlerde ve 10 ile 30 . günlerde saptanmıştır. $\mathrm{N} / \mathrm{L}$ maksimum oranı pik beyaz küre sayımının elde edildiği kan sayımından oranlanarak elde edilmiştir. Myoglobulin kütle CK-MB ve troponin düzeyleri 4, 8, 12, 24, 48. saatlerde bakılmış olup; troponin değerleri 10 ile 30 günlerde de takip edilmiştir. Diğer tüm kan testleri otomatik ölçüm cihazları ile rutin prosedürler dâhilinde yapılmıştır.

\section{Periferik kök hücre sayımı}

Çalışmaya dâhil edilen tüm hastaların bazal, 10. ve 30. günlerde EDTA ile antikoagüle edilmiş periferik kan örneği alınarak; flowsitometrik yöntem ile CD34+, CD45+ kemik iliği kaynaklı kök hücre konsantrasyonları belirlenmiştir. Tam kan örnekleri kan alımından sonra 6 saat içerisinde işleme alınmıştır. Örnekler fikoeritrin ile konjuge edilmiş anti-CD45 ve anti- CD34 monoklonal antikorları (Beckton Dickinson) ile $40^{\circ} \mathrm{C}$ 'de 15 dakika boyuca boyandıktan sonra amonyum klorid ile lisise uğratılmıştır. Santirifüj sonrası örnekler flowsitometri cihazı (Beckton Dickinson) ile analiz edilmiştir. CD34 (+) kök 
hücre düzeyleri flowsitometrik analiz sonrası tüm beyaz kürelerin yüzdesi olarak saptanmıştır. CD34 (+) kök hücre yüzdeleri total beyaz küre sayısı ile çarpılarak CD34 (+) kök hücre sayısı hesaplanmıştır.

\section{Bulgular}

Çalışmaya; ilk kez akut miyokard enfarktüsü ile başvuran toplam 28 hasta alınmış olup; hastaların demografik ve klinik verileri Tablo 1 'de belirtilmiştir.

\section{Beyaz küre sayımları}

Hastaların başvuru sırasındaki beyaz küre sayımı ortalaması (BK) 12150 \$3376 /

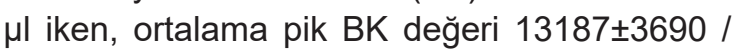
$\mu l$ olarak saptanmıştır $(p=0,001)$. Ortalama bazal nötrofil değeri $8499 \pm 3466 / \mu l$ iken, pik nötrofil değeri ortalaması $9501 \pm 3920 / \mu$ l olarak saptanmıştır $\quad(p=0,001)$. Ortalama lenfosit değeri başvuru sırasında 2568 $\pm 1289 / \mu$ iken; AMI seyri sırasındaki en düşük (dip) lenfosit değerleri ortalaması $2395 \pm 1078 / \mu$ l olarak tespit edilmiştir $(p=0,05)$. Bir aylık izlem sonrasında

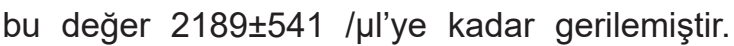
Hastaların başvuru sırasındaki beyaz küre ve nötrofil sayımları AMl'ın hastane sürecinde artış gösterirken; 30. günde bazal değerlere göre belirgin azalma saptanmıştır $(p=0,001)$ (Şekil 1, 2).

Total beyaz küre sayıları ile kardiyak enzim düzeyleri arasında anlamlı korelasyon saptanmaz iken; bazal ve pik nötrofil düzeyleri ile CK-MB düzeyleri arasında pozitif korelasyon saptanmıştır $(r=0,538, p=0,03$ ve $r=0,457$, $p=0,01)$. Bazal lenfosit sayımları, CK-MB ile güçlü ve troponin-I ile orta düzeyde negatif korele olarak saptanmıştır ( $r=-0,668, p=0,001$ ve $r=-0,465, p=0,01)$. Dip lenfosit düzeyleri de CK-MB ve troponin-I ile orta düzeyde negatif

Tablo 1. Hastaların demografik, klinik özellikleri ve risk faktörleri

\begin{tabular}{lll}
\hline Veri adı & Sayı & Yüzde \\
\hline Yaş (yıl) & $56,3 \pm 11$ & - \\
Erkek/Kadın & $22 / 6$ & $\% 78 / \% 22$ \\
Diabetes Mellitus & 3 & $\% 10$ \\
Hipertansiyon & 9 & $\% 32$ \\
Hiperlipidemi & 4 & $\% 14$ \\
Sigara & 20 & $\% 71$ \\
Aile Öyküsü & 5 & $\% 18$ \\
BMI & $26,2 \pm 6,38$ & - \\
Betabloker & 2 & $\% 7$ \\
ACE inhibitörü / ARB & 5 & $\% 18$ \\
Antiagregan & 3 & $\% 10$ \\
Statin & 0 & $\% 0$ \\
Killip klas I & 25 & $\% 90$ \\
Killip klas II & 3 & $\% 10$ \\
Sistolik kan basıncı (mmHg) & $119 \pm 20$ & - \\
Bazal SVEF (\%) & $48 \pm 6,95$ & - \\
SVDSÇ (cm) & $49 \pm 4,8$ & - \\
SVSSÇ(cm) & $33 \pm 5,1$ & - \\
DHSi bazal & $1,59 \pm 0,32$ & - \\
Tek damar & 5 & $\% 18$ \\
Çok damar & 23 & - \\
Gensini skoru & $52 \pm 21$ & - \\
Başvuru zamanı (saat) & $4,1 \pm 1,9$ & - \\
\hline & & \\
\hline
\end{tabular}

BMI: Vücut kitle indeksi, ACE: Angiotensin dönüştürücü enzim inhibitörü ARB: Angiotensin reseptör blökörü, SVEF: Sol ventrikül ejeksiyon fraksiyonu SVDSÇ: Sol ventrikül diastol sonu çapı, SVSSÇ: Sol ventrikül sistol sonu çapı DHSI: Duvar hareket skor indeksi 


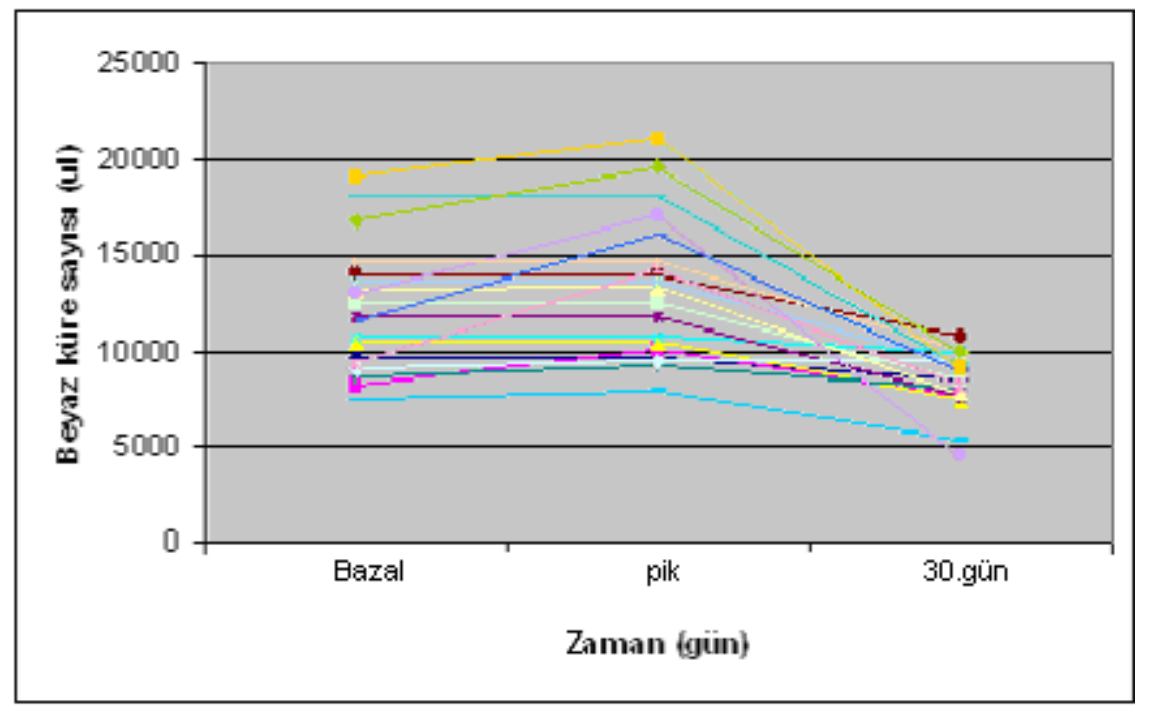

Şekil 1. Zamana göre beyaz küre değişim grafiği

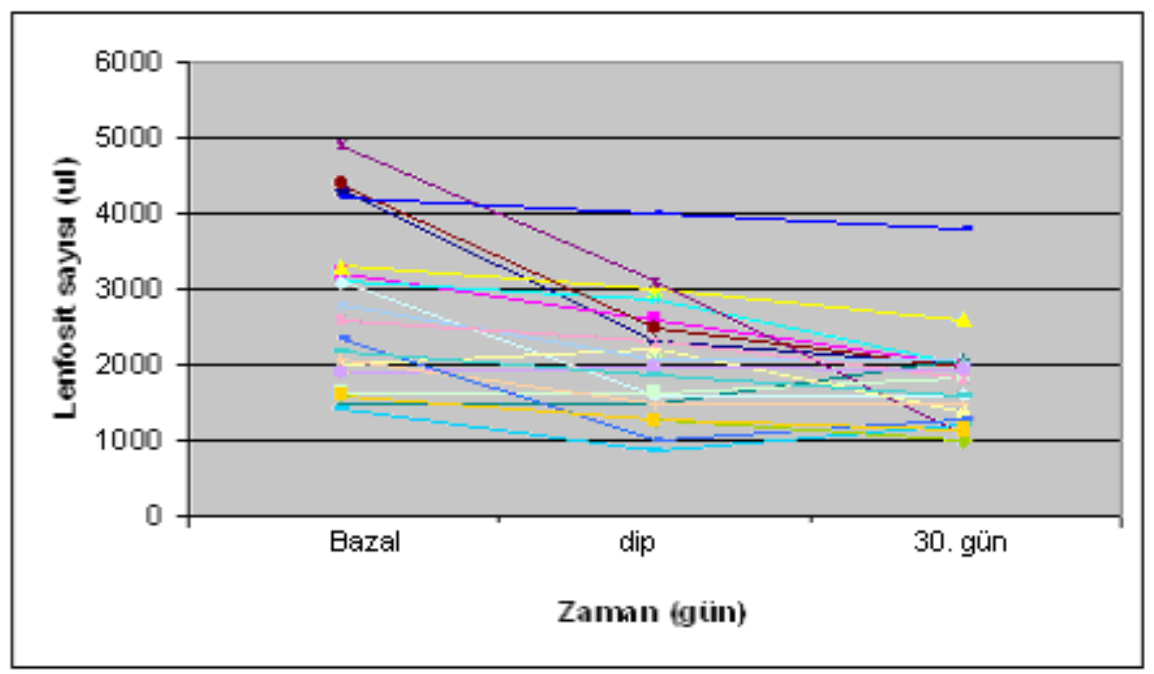

Şekil 2. Zamana göre lenfosit değişim grafiği

korele olarak saptanmıştır $(r=-0,4890, p=0,08$ ve $r=-0,420, p=0,01$ ) (Tablo 2 ).

Bazal ve pik BK ile ekokardiyografik parametreler arasında anlamlı düzeyde korelasyon saptanmamıştır. Hastaların semptom başlangıcından hastaneye başvurusuna kadar geçen ortalama süre $4,1 \pm 1,9$ saat olmakla birlikte bazal nötrofil değerleri ile başvuru zamanı arasında pozitif korelasyon saptanmıştır $(r=0,527, p=0,04)$. Nötrofil değerleri ile SVEF arasında korelasyon saptanmazken; 30. gün DHSí değerleri arasında orta düzeyde pozitif korelasyon saptanmıştır $(r=0,532, p=0,01)$. Bazal lenfosit düzeyleri ile DHSI arasında negatif korelasyon saptanmıştır $(r=-0,548, p=0,04)$. Dip lenfosit düzeyleri ile SVEF arasında pozitif korelasyon saptanırken
DHSi ile negatif korelasyon saptanmıştır ( $r=$ $0,403, p=0,03$ ve $r=-0,598, p=0,01)$.

CRP düzeyleri ile SVEF ve 30. gün DHSi değerleri arasında zayıf düzeyde pozitif korelasyon saptanmıştır $(\mathrm{r}=0,434, \quad p=0,02$ ve $r=0,470, p=0,01)$. Bazal nötrofil/lenfosit oranları ile zaman arasında orta düzeyde pozitif korelasyon saptanırken $(r=0,574, \quad p=0,01)$; bazal ve pik nötrofil/lenfosit oranları ile DHSi 30. gün değerleri arasında zayıf düzeyde pozitif korelasyon saptanmıştır $(r=0,428, p=0,02$ ve $r=0,374, p=0,05)$. Yalnızca bazal ve pik lenfosit değerleri başvuru sırasındaki DHSi ile negatif korele bulunmuştur $(r=-0,430, p=0,02$ ve $r=-$ $0,417, p=0,02$ ) (Tablo 3). 
Tablo 2. Beyaz küre düzeylerinin laboratuvar parametreleri ile korelasyonu

\begin{tabular}{lclllll}
\hline & \multicolumn{2}{c}{ CKMB $(\mathbf{n g} / \mathbf{m l})$} & \multicolumn{2}{c}{ Troponin I $(\mathbf{n g} / \mathbf{m l})$} & \multicolumn{2}{c}{ CRP $(\mathbf{m g} / \mathbf{d l})$} \\
\hline & $\mathrm{r}$ & $p$ değeri & $r$ & $p$ değeri & $r$ & $p$ değeri \\
\hline Bazal nötrofil $(\boldsymbol{\mu l})$ & 0,538 & 0,03 & - & - & - & - \\
Pik nötrofil $(\boldsymbol{\mu l})$ & 0,457 & 0,01 & - & - & - & - \\
Bazal lenfosit $(\boldsymbol{\mu l})$ & $-0,668$ & 0,001 & $-0,465$ & 0,01 & - & - \\
Dip lenfosit $(\boldsymbol{\mu l})$ & $-0,489$ & 0,008 & $-0,420$ & 0,01 & - & - \\
\hline
\end{tabular}

CKMB: Kreatinin kinaz, CRP: C-reaktif protein, BK: Beyaz küre sayımı

(-) ile belirtilen hücrelerde istatistiksel anlamlılık saptanmamıştır

Tablo 3. Beyaz küre düzeylerinin ekokardiyografik ve klinik parametreler ile korelasyonu

\begin{tabular}{llllllllll}
\hline & \multicolumn{1}{c}{ SVEF 30 } & \multicolumn{2}{c}{ DHSi } & \multicolumn{3}{c}{ DHSi 30 } & \multicolumn{2}{c}{ Başvuru zamanı } \\
\hline & $\mathrm{r}$ & $p$ & $\mathrm{r}$ & $p$ & $\mathrm{r}$ & $p$ & $\mathrm{r}$ & $p$ \\
\hline Bazal nötrofil $(\boldsymbol{\mu l})$ & - & - & - & - & 0,532 & 0,01 & 0,527 & 0,04 \\
Pik nötrofil $(\boldsymbol{\mu l})$ & - & - & - & - & 0,374 & 0,05 & - & - \\
Bazal lenfosit $(\boldsymbol{\mu l})$ & - & - & $-0,430$ & 0,02 & $-0,548$ & 0,04 & $-0,449$ & 0,01 \\
Dip lenfosit $(\boldsymbol{\mu l})$ & 0,403 & 0,03 & $-0,417$ & 0,02 & $-0,598$ & 0,01 & - & - \\
Nötrofil/lenfosit bazal & - & - & - & - & 0,428 & 0,02 & 0,574 & 0,01 \\
Nötrofil/lenfosit pik & - & - & - & - & 0,374 & 0,05 & - & - \\
\hline
\end{tabular}

BK: Beyaz küre sayımı, SVEF 30: Otuzuncu gün sol ventrikül ejeksiyon fraksiyonu

DHSI: Duvar hareket skor indeksi, DHSI 30: Otuzuncu gün duvar hareket skor indeksi

CRP: C-reaktif protein. (-) ile belirtilen hücrelerde istatistiksel anlamlılık saptanmamıştır

\section{CD34 (+) kök hücre sayımları}

CD34 (+) kök hücrelerin toplam beyaz küre sayımına oranı başvuru sırasında $\% 0,03 \pm 0,02$ iken birinci ayda $\% 0,04 \pm 0,017$ olarak saptanmıştır $(p=0,05)$. CD34 $(+)$ kök hücreler sayı olarak değerlendirildiğinde ise başvuru sırasında ortalama değer $369 \pm 244 / \mu$ iken onuncu günde $368,5 \pm 126 / \mu \mathrm{l}$, otuzuncu günde ise $335 \pm 170 / \mu \mathrm{l}$ olarak saptanmıştır $(p=0,750)$. CD34 (+) kök hücre sayı ve yüzdeleri ile kardiyak enzim düzeyleri arasında anlamlı korelasyon saptanmamıştır. CD34 (+) kök hücre sayı ve yüzdeleri ile DHSl'deki değişim arasında orta düzeyde negatif korelasyon saptanmıştır ( $r=-$ $0,562, p=0,008$ ve $r=-0,532, p=0,01)$. CD34 (+) kök hücre sayı ve yüzdeleri ile SVEF'deki değişim arasında pozitif korelasyon saptanmıştır $(\mathrm{r}=0,585, p=0,005$ ve $\mathrm{r}=0,438, p=0,04$ ) (Tablo 4). CD34 (+) kök hücre sayıları ile bazal BK, bazal ve pik nötrofil sayımları arasında negatif korelasyon saptanmıştır $(r=-0,476, p=0,029)$.

\section{Tartışma}

Çalışmamızda özellikle lenfosit düzeylerinin; kardiyak enzimler, LVEF, DHSi gibi ekokardiyografik parametreler ileri derecede korele olduğu bulunmuştur [17-20]. Hastaların, başvuru sırasındaki beyaz küre ve nötrofil sayımları AMI sırasında artış gösterirken; 30. günde normal düzeylere dönmüştür. Yapılan çalışmalarda da; AMI sonrası nötrofil düzeylerinin başarılı reperfüzyon ile düşüşe geçtiği görülmektedir [21]. Çalışmamızda nötrofil düzeylerinden farklı olarak; lenfosit düzeylerinin, AMI seyrinde düşüş gösterdiği ve bu düşüşün 30 . gün ölçümlerinde de sebat ettiği görülmüştür. Lenfosit düzeylerindeki azalma; stres sırasındaki kortizol yanıtının; lenfositlerin tüm beyaz küreler içindeki rölatif konsantrasyonunu azaltmasına bağlanmaktadır $[22,23]$. AMI seyri sırasında CD4/CD8 T lenfosit oranı ters dönmektedir. Lenfopeni ile birlikte bu oranın uzun süre ters dönmüş olarak sebat etmesi; olumsuzsonuçlarile ilişkilidir [24,25]. Zira CD4 (+) T lenfositler immün sistemi dolayısıyla inflamasyonu tetikler iken; CD8 lenfositler baskılayıcı rol oynamaktadırlar. Ayrıca; akut miyokard infarktüsü ve ani kardiyak ölüm gelişen hastalarda aktive t-lenfosit infiltratlarının infarkt ve perienfarkt bölge ile infarktla ilişkili arterlerin duvarlarında birikimi daha önce gösterilmiştir [26, 27]. ST segment elevasyonsuz MI geçiren hastalarda da periferal lenfositlerin aşırı aktive 
Tablo 4. CD34 düzeylerinin ekokardiyografik parametreler ve zaman ile korelasyonu

\begin{tabular}{lllllll}
\hline & \multicolumn{2}{l}{ SVEF değişim } & \multicolumn{2}{l}{ DHSi değişim } & \multicolumn{2}{c}{ Başvuru zamanı } \\
\hline & $r$ & $p$ değeri & $r$ & $p$ değeri & $r$ & $p$ değeri \\
CD34 yüzdesi $(\%)$ & 0,438 & 0,04 & $-0,532$ & 0,01 & - & - \\
CD34 sayı $(\mu \mathrm{l})$ & 0,585 & 0,005 & $-0,562$ & 0,008 & - & - \\
\hline
\end{tabular}

SVEF: Sol ventrikül ejeksiyon fraksiyonu, DHSI: Duvar hareket skor indeksi

(-) ile belirtilen hücrelerde istatistiksel anlamlılık saptanmamıştır

olarak plak rüptürüne katkıda bulunduğu ve artmış programlanmış hücre ölümüne maruz kalarak sayılarının azaldığı saptanmıştır [28, 29]. Lenfopeni aracılıklı immünsüpresyonun görüldüğü edinilmiş immün yetmezlik sendromu, posttransplant immün yetmezlik sendromu gibi hastalıklarda; CD4 (+) T lenfositlerde düşüşle birlikte artmış bir aterosklerotik süreç görülmektedir [30]. Lenfopeni düzeyleri sebep ya da sonuç olsun; karşımıza önemli bir risk faktörü olarak ortaya çıkmaktadır.

Çalışmamızda, beyaz küre alt grup sayımlarının LVEF ve DHSl'de toparlanma ile ilişkili olduğu görülmektedir. Total beyaz küre sayımı ile enzimatik miyokard nekroz markerları (troponin, CK-MB) arasında ilişki saptanmazken; nötrofil ve lenfosit gibi alt gruplar ile yüksek düzeyde ilişki saptanmıştır. Çalışmamızda; kardiyak enzimler ile en belirgin korelasyon lenfosit düzeyleri ile saptanmıştır. Lenfosit düzeylerinin nötrofiller gibi başarıı reperfüzyon sonrası hemen normal düzeylere dönmediği görülmektedir. Ayrıca çalışmamızda; dip lenfosit düzeylerinin hem bazal hem de 30. gün SVEF ve DHSI ile korele olduğu görülmektedir. Yapılan benzer çalışmalarda, akut miyokard infarktüsü seyrinde; düşük CD4/CD8 lenfosit oranı ve düşük CD4 hücre sayımlarının düşük ejeksiyon fraksiyonu ve yüksek kardiyak enzim düzeyleri, artmış tekrarlayan infarktüs ve ölüm ile ilişkili olduğu görülmektedir [31, 32].

Nötrofillerin ömürleri saatlerle sınırlı olmakla birlikte her bireyde benzer şekilde nonspesifik bir immün yanıt oluşturmaktadırlar. Lenfositler ise daha uzun süreler yaşayan hücrelerdir ve her biri patojene spesifik olarak baştan kodlanmışlardır [33]. Ayrıca lenfositler vücudun inflamasyona yanıtını düzenleyen temel hücrelerdir ve diğer inflamatuvar hücreleri (nötrofiller, monositler) salgıladıkları sitokinler ile hasarlı bölgeye çekmektedirler.

Çalışmamızda saptadığımız üzere; lenfosit düzeylerindeki değişikliklerin hem bir ay boyunca sebat etmesi hem de diğer beyaz küre alt gruplarına göre AMI sonrası sol ventriküler fonksiyonel toparlanma ile daha yüksek derecede korelasyon saptanması özellikle ilgi çekicidir. Bulgularımız; beyaz küre alt gruplarından özellikle lenfosit sayımlarının akut miyokard infarktüsü seyrinde kardiyak enzim düzeyleri ve ekokardiyografik parametreler ile korele sonuçlar verdiğini göstermektedir. Tüm bu çalışmalardaki bulgular ile birlikte bizim verilerimiz; lenfositlerin AMI seyrinde aktif rollerinin olduğunu ve lenfopeni düzeylerinin biyomarker olarak kullanılabileceğini düşündürmektedir.

Çalışmamızda ayrıca akut MI seyri sırasında; CD34 (+) kök hücre sayı ve yüzdelerinin, kardiyak enzim düzeyleri ve ekokardiyografik parametreler ile ilişkisi incelenmiştir. CD34 (+) kök hücre düzeylerinin bazal ve 30 . gün ekokardiyografik parametreler ve bu parametrelerdeki düzelme ile ilişkili olduğu görülmüştür. Koroner arter hastalığı olan bireylerde; risk faktörlerine bağlı olarak; normal kontrollere göre periferik kanda kök hücre sayılarının daha düşük ve fonksiyonlarının daha azalmış olduğu saptanmıştır [34]. Miyokard infarktüsü gibi akut durumlarda ise miyositler ve koroner dolaşımla birlikte infarkt alanındaki kök hücreler de kaybedilmektedir [35].

Çalışmamızda bazal ile 10. gün arasında CD34 (+) kök hücrelerin düzeylerinde yüzde olarak artış izlenirken; 10. günde total beyaz küre sayısındaki azalmayla birlikte, CD34 (+) kök hücre sayılarında göreceli bir düşüş izlenmiştir. Buna bağlı olarak bazal ile 10 ve 30.gün sayımları arasında istatistiksel olarak anlamlı farklılık saptanmıştır. Kök hücre sayımları arasında; istatistiksel olarak anlamlı bir farklılık saptanmaması, çalışmamızdaki denek sayısının yetersiz olmasına veya pik değerlerin seyrek örnekleme bağlı olarak atlanmış olmasına bağlı olabilir. Yine de; CD 34 (+) kök hücre düzeyleri, SVEF'deki değişim ve DHSl'deki değişim ile korele olarak saptanmıştır. 
Benzer şekilde başka bir çalışmada ejeksiyon fraksiyonu \%40'ın altında olanlarda; CD34 pozitif kök hücre sayısının anlamlı derecede azaldığı saptanmıştır [36].

Çalışmamızda akut koroner sendrom seyri sırasında CD34 (+) kök hücre düzeylerinin SVEF toparlanması ile korele olduğu bulunmuştur ancak CD34 (+) kök hücreler ile nekroz markerları olan kardiyak enzim düzeyleri arasında herhangi bir bağıntı saptanamamıştır.

Sonuç olarak, akut miyokard infarktüsü sırasında bakılan, periferik kandaki kök hücre sayımları sol ventrikül fonksiyonlarında ekokardiyografik düzelmenin belirteci olarak ortaya çıkmaktadır.

Çıkar ilişkisi: Yazarlar çıkar ilişkisi olmadığını beyan eder.

\section{Kaynaklar}

1. Ross R. Atherosclerosis an inflammatory disease. $\mathrm{N}$ Engl J Med 1999;340:115-126. https://doi.org/10.1056/ NEJM199901143400207

2. Shah PK. New insights into the pathogenesis and prevention of acute coronary syndromes. Am J Cardiol 1997;79:17-23. https://doi.org/10.1016/s00029149(97)00381-0

3. Davies MJ, Richardson PD, Woolf N, Katz DR, Mann J. Risk of thrombosis in human atherosclerotic plaques: role of extracellular lipid, macrophage, and smooth muscle cell content. Br Heart J 1993;69:377-381. https://doi.org/10.1136/hrt.69.5.377

4. Libby P. Molecular bases of the acute coronary syndromes. Circulation 1995;91:2844-2850. https://doi.org/10.1161/01.cir.91.11.2844

5. Nijm J, Wikby A, Tompa A, Olsson AG, Jonasson L. Circulating Levels of proinflammatory cytokines and neutrophil-platelet aggregates in patients with coronary artery disease. Am J Cardiol 2005;95:452-456. https://doi.org/10.1016/j.amjcard.2004.10.009

6. Lee CD, Folsom AR, Nieto FJ, Chambless LE, Shahar E, Wolfe DA. White blood cell count and incidence of coronary heart disease and ischemic stroke and mortality from cardiovascular disease in African-merican and White men and women: atherosclerosis risk in communities study. Am J Epidemiol 2001;154:758-764. https://doi.org/10.1093/aje/154.8.758

7. Brown DW, Giles WH, Croft JB. White blood cell count: an independent predictor of coronary heart disease mortality among a national cohort. J Clin Epidemiol 2001;54:316-322. https://doi.org/10.1016/s0895-4356(00)00296-1
8. Folsom AR, Wu KK, Rosamond WD, Sharrett AR, Chambless LE. Prospective study of hemostatic factors and incidence of coronary heart disease: the Atherosclerosis Risk In Communities (ARIC) study. Circulation 1997;96:1102-1108. https://doi.org/10.1161/01.cir.96.4.1102

9. Prentice RL, Szatrowski TP, Fujikura $T$, Kato $H$, Mason MW, Hamilton $\mathrm{HH}$. Leukocyte counts and coronary heart disease in a Japanese cohort. Am J Epidemiol 1982;116:496-509. https://doi.org/10.1093/oxfordjournals.aje.a113434

10. Olivares $R$, Ducimetiere $P$, Claude JR. Monocyte count: a risk factor for coronary heart disease? Am J Epidemiol 1993;137:49-53. https://doi.org/10.1093/oxfordjournals.aje.a116601

11. Takahashi T, Kalka C, Masuda $\mathrm{H}$, et al. Ischemiaand cytokine-induced mobilization of bone marrow-derived endothelial progenitor cells for neovascularization. Nat Med 1999;5:434-438. https://doi.org/10.1038/7434

12. Leone AM, Rutella $S$, Bonanno $G$, et al. Mobilization of bone marrow-derived stem cells after myocardial infarction and left ventricular function. Eur Heart J 2005;26:1196-1204. https://doi.org/10.1093/eurheartj/ehi164

13. Alpert JS, Thygesen K, Antman E, Bassand JP. Myocardial infarction redefined: a consensus document of The Joint European Society of Cardiology/American College of Cardiology Committee for the redefinition of myocardial infarction. Eur Heart J 2000;21:1502-1513. https://doi.org/10.1053/euhj.2000.2305

14. Van de WF, Ardissino D, Betriu A, et al. Management of acute myocardial infarction in patients presenting with ST-segment elevation: the Task Force on the Management of Acute Myocardial Infarction of the European Society of Cardiology. Eur Heart J 2003;24:28-66. https://doi.org/10.1016/s0195$668 \times(02) 00618-8$

15. Schiller NB, Shah PM, Crawford $M$, et al. Recommendations for quantitation of the left ventricle by two-dimensional echocardiography. American Society of Echocardiography Committee on Standards, Subcommittee on Quantitation of Two-Dimensional Echocardiograms. J Am Soc Echocardiogr 1989;2:358367. https://doi.org/10.1016/s0894-7317(89)800148

16. Sullivan DR, Marwick TH, Freedman SB. A new method of scoring coronary angiograms to reflect extent of coronary atherosclerosis and improve correlation with major risk factors. Am Heart J 1990;119:1262-1267. https://doi.org/10.1016/s0002-8703(05)80173-5

17. Shinozaki K, Tamura A, Watanabe $T$, et al. Significance of neutrophil counts after reperfusion therapy inpatients with a first anterior wall acute myocardial infarction. Circ J 2005;69:526-529. https://doi.org/10.1253/circj.69.526 
18. Takahashi T, Hiasa Y, Ohara $\mathrm{Y}$, et al. Relationship of admission neutrophil count to microvascular injury, left ventricular dilation, and long-term outcome in patients treated with primary angioplasty for acute myocardial infarction. Circ J 2008;72:867-872. https://doi.org/10.1253/circj.72.867

19. Mariani M, Fetiveau R, Rossetti E, et al. Significance of total and differential leucocytes count in patients with acute myocardial infarction treated with primary coronary angioplasty. Eur Heart J 2006;27:2511-2515. https://doi.org/10.1093/eurheartj/ehl191

20. Núñez J, Núñez $E$, Bodí $V$, et al. Usefulness of the neutrophil to lymphocyte ratio in predicting longterm mortality in ST segment elevation myocardial infarction. Am J Cardiol 2008;101:747-752. https://doi.org/10.1016/j.amjcard.2007.11.004

21. Wong CK, French JK, Gao W, White HD. Relationship between initial white blood cell counts, stage of acute myocardial infarction evolution at presentation, and incidence of Thrombolysis In Myocardial Infarction-3 flow after streptokinase. Am Heart J 2003;145:95-102. https://doi.org/10.1067/mhj.2003.64

22. Thomson SP, McMahon LJ, Nugent CA. Endogenous cortisol: a regulator of the number of lymphocytes in peripheral blood. Clin Immunol Immunopathol 1980;17:506-514. https://doi.org/10.1016/0090-1229(80)90146-4

23. Ommen SR, Hodge DO, Rodeheffer RJ, McGregor CGA, Thomson SP, Gibbons RJ. Predictive power of the relative lymphocyte concentration in patients with advanced heart failure. Circulation 1998;97:19-22. https://doi.org/10.1161/01.cir.97.1.19

24. Widmer A, Linka $\mathrm{AZ}$, Attenhofer Jost $\mathrm{CH}$, et al. Mechanical complications after myocardial infarction reliably predicted using Creactive protein levels and lymphocytopenia. Cardiology 2003;99:25-31. https://doi.org/10.1159/000068448

25. Hotchkiss RS, Karl IE. The pathophysiology and treatment of sepsis. N Engl J Med 2003;348:138-150. https://doi.org/10.1056/NEJMra021333

26. Abbate A, Bussani R, Liuzzo G, et al. Sudden coronary death, fatal acute myocardial infarction and widespread coronary and myocardial inflammation. Heart 2008;94;737-742. https://doi.org/10.1136/hrt.2007.115329

27. Spagnoli LG, Bonanno E, Mauriello A, et al. Multicentric inflammation in epicardial coronary arteries of patients dying of acute myocardial infarction. J Am Coll Cardiol 2002;40:1579-1588. https://doi.org/10.1016/s0735-1097(02)02376-8

28. Pasqui AL, Di Renzo M, Bova G, et al. Lymphocyte apoptosis in non-ST segment elevation acute myocardial infarction. Ann Ital Med Int 2003;18:154161.
29. Bossowska A, Bossowski A, Galar B. Analysis of apoptotic markers Fas/FasL (CD95/CD95L) expression on the lymphocytes in patients with acute coronary syndrome. Kardiol Pol 2007;65:883-889.

30. Ducloux D, Challier B, Saas P, Tiberghien P, Chalopin JM. CD4 cell lymphopenia andatherosclerosis in renal transplantrecipients.JAmSocNephrol2003;14:767-772. https://doi.org/10.1097/01.asn.0000048718.43419.44

31. Blum A, Sclarovsky S, Rehavia E, Shohat B. Levels of T-lymphocyte subpopulations, interleukin-1 beta, and soluble interleukin-2 receptor in acute myocardial infarction. Am Heart J 1994;27:1226-1230. https://doi.org/10.1016/0002-8703(94)90040-x

32. Al Ahmad RS, Mahafzah AM, Al Mousa EN. Immunological changes in acute myocardial infarction. Saudi Med J 2004;25:923-928.

33. Goronzy JJ, Weyand CM. Immunosuppression in atherosclerosis. Circulation 2006;114:1901-1904. https://doi.org/10.1161/ CIRCULATIONAHA.106.656751

34. Vasa M, Fichtlscherer S, Aicher A, et al. Number and migratory activity of circulating endothelial progenitor cells inversely correlate with risk factors for coronary artery disease. Circ Res 2001;89:1-7.

35. Asahara T, Masuda $\mathrm{H}$, Takahashi $\mathrm{T}$, et al. Bone marrow origin of endothelial progenitor cells responsible forpostnatal vasculogenesis in physiological and pathological neovascularization. Circ Res 1999;85:221228. https://doi.org/10.1161/01.res.85.3.221

36. Wojakowski W, Tendera M, Zebzda A, et al. Mobilization of CD34(+), CD117(+), CXCR4(+), c-met(+) stem cells is correlated with left ventricular ejection fraction and plasma NT-proBNP levels in patients with acute myocardial infarction. Eur Heart J 2006;27:283-289. https://doi.org/10.1093/eurheartj/ehi628

Etik kurul onayı: Bu çalışmanın etik kurul izni, Pamukkale Üniversitesi Girişimsel Olmayan Klinik Araştırmalar Etik Kurulu'nun 07/07/2008 tarihinde alınmıştır.

\section{Yazarların makaleye olan katkıları}

H.T. çalışmanın ana fikrini ve hipotezini kurgulamışdır. Ö.T ve H.T. teoriyi geliştirmiş, gereç ve yöntem bölümünü düzenlemişlerdir. Sonuçlar kısmındaki verilerin değerlendirmesini Ö.T. ve H.T. yapmışlardır. Makalenin tartışma bölümü Ö.T. tarafından yazıımış, H.T. tarafından gözden geçirip gerekli düzeltmeleri yapmış ve onaylamıştır. T.D. çalışmanın istatistiklerinin yapılması ve sonuçların yorumlanması konusunda görev almıştır. Ayrıca tüm yazarlar çalışmanın tamamını tartışmış ve son halini onaylamıştır. 